\title{
Effect of Temperature on Symptoms Expression and Viral RNA Accumulation in Groundnut Bud Necrosis Virus Infected Vigna unguiculata
}

\author{
Ajeet Singh ${ }^{1 *}$, Vipin Permar ${ }^{2}$, Basavaraj ${ }^{2}$, Bhoopal Singh Tomar ${ }^{3}$, Shelly Praveen ${ }^{1 *}$ \\ ${ }^{1}$ Division of Biochemistry, Indian Agricultural Research Institute, New Delhi-110012, India \\ 2 Division of Plant Pathology, Indian Agricultural Research Institute, New Delhi-110012, India \\ ${ }^{3}$ Division of Vegetable Science, Indian Agricultural Research Institute, New Delhi-110012, India \\ ${ }^{*}$ Corresponding author: Ajeet Singh, Division of Biochemistry, Indian Agricultural Research Institute, New Delhi-110012, India \\ Tel.: +91 1125843474; Fax: +91 1125840772. E-mail: dhakaajeet9961@gmail.com (A. singh)
}

Received: 24 Feb. 2017; $\quad$ Revised: 19 Jan. 2018; $\quad$ Accepted: 20 Jan. 2018; Published online: 11 Aug. 2018

\begin{abstract}
Background: Groundnut bud necrosis virus (GBNV) (Tospovirus genus, Bunyaviridae family) infects the major crops of solanaceae, leguminosae and cucurbitaceae in India. Temperature is an important factor which influences the plant growth and development under diseased conditions.

Objective: In the present study, we evaluated the effect of four different temperatures on the symptoms expression and viral RNA accumulation in the GBNV inoculated cowpea plants.

Material and Methods: For the evaluation of viral symptoms and RNA accumulation, we used 2-3 leaf stage cowpea plants grown in the controlled conditions. GBNV was mechanically inoculated by sap method to the cowpea plants and inoculated plants were incubated at four different temperatures $\left(30,25,20\right.$ and $\left.15^{\circ} \mathrm{C}\right)$.

Results: The first visible symptom of GBNV infection at the inoculated site was observed in the form of chlorotic spots which were converted into the necrotic spots as the infections succeeded. Some yellow mosaic symptoms were also observed at the systemic site during viral infection cycle. Plants incubated at higher $\left(30\right.$ and $\left.25^{\circ} \mathrm{C}\right)$ temperatures showed a severe necrosis and a higher viral RNA accumulation at the inoculated site and facilitated the viral spread at the systemic site. However, viral RNA accumulation was less at the systemic site than the inoculated site. In contrast, symptoms' expression and viral RNA accumulation were decreased at the inoculated site at low $\left(20\right.$ and $\left.15^{\circ} \mathrm{C}\right)$ temperatures, no viral symptoms were observed at the systemic site $\left(15^{\circ} \mathrm{C}\right)$; in addition to viral RNA accumulation suppression at this site. GBNV infection at the inoculated site induced the higher accumulation of $\mathrm{H}_{2} \mathrm{O}_{2}$ followed by the induction of cell death at higher temperatures $\left(30\right.$ and $\left.25^{\circ} \mathrm{C}\right)$ than the lower $\left(20\right.$ and $\left.15^{\circ} \mathrm{C}\right)$ temperatures.

Conclusion: This study suggests that viral RNA accumulation parallels with the $\mathrm{H}_{2} \mathrm{O}_{2}$ production and induction of cell death by GBNV infection in cowpea plants is temperature dependent.

Keywords: Chlorosis; $\mathrm{H}_{2} \mathrm{O}_{2}$; Hypersensitive response (HR); Programmed cell death (PCD); Necrosis
\end{abstract}

\section{Background}

Temperature is one of the most important environmental factors that affect plant-pathogen interactions, and it can either increase or decrease disease resistance. This reflects the differential influence of the same temperature variation on different plants. Temperature affects the growth and populations of microorganisms living on plants such as viruses. Several reports have given the contradictory data on the temperatures favoring viral replication, which depend on the virus species as well as the analyzed host plant. It has been reported that temperature affects the viral transmission, replication and translocation inside the plant, as well as susceptibility, and symptom expression in the host. Tomato spotted wilt virus (TSWV) infection in tomato shows a higher replication at $20^{\circ} \mathrm{C}$ while symptoms are

Copyright (C 2017 The Author(s); Published by National Institute of Genetic Engineering and Biotechnology. This is an open access article, distributed under the terms of the Creative Commons Attribution-NonCommercial 4.0 International License (http://creativecommons.org/licenses/ by-nc/4.0/) which permits others to copy and redistribute material just in noncommercial usages, provided the original work is properly cited. 
more severe at $36{ }^{\circ} \mathrm{C}$ (1). Turnip crinkle virus (TCV) is rigorously replicated under the high temperature in Arabidopsis plants (2). A higher temperature facilitates the spread of the Tobacco mosaic virus (TMV) or Turnip mosaic virus (TuMV) by weakening plant defense responses (3). The importance of the temperature on virus infection and accumulation is under intense investigation (4-6).

Groundnut bud necrosis virus (GBNV), a member of the genus Tospovirus and the family Bunyaviridae, is a devastating thrips-transmitted virus. GBNV induces chlorotic and necrotic spots, mosaic, mottling and yellowing on leaves. Tospoviruses are $80-120 \mathrm{~nm}$ in diameter, quasi-spherical and defined by a membranous envelope contain two types of glycoproteins designated as $\mathrm{G} 1(78 \mathrm{kDa})$ and $\mathrm{G} 2(50 \mathrm{kDa})$. The envelope covers a tripartite RNA genome which is tightly packaged by numerous copies of the nucleocapsid $(\mathrm{N})$ protein subunits $(29 \mathrm{kDa})$ and $10-20$ copies of a large (L) protein, which is the putative RNA dependent RNA polymerase. The L RNA ( $9 \mathrm{~kb}$ ) has a single ORF in the viral complementary sense and encodes the RNA polymerase of $331.5 \mathrm{kDa}$ (7). The M RNA is also ambisense and approximately $4.8 \mathrm{~kb}$, which contains two ORFs. The M RNA encodes for the glycoproteins G1 and G2 in the viral complementary sense RNA (vcRNA) and a nonstructural movement protein (NSm) in the viral sense RNA (vcRNA). The G1/G2 proteins are highly conserved amongst tospoviruses than the $\mathrm{N}$ protein. The extra NSm gene therefore may reflect an adaptation of the tospovirus to the plant hosts, i.e. it may act as the movement protein. The S RNA is ambisense and approximately $3 \mathrm{~kb}(7,8)$, which contains two ORFs. The ORF adjacent to the $5^{\prime}$ end of the RNA codes for a nonstructural protein in the viral sense designated NSs (52.4 kDa) whose function has not been determined. The ORF adjacent nearer to the $3^{\prime}$ end is in the viral complementary sense strand and codes for the $\mathrm{N}$ protein; a $29 \mathrm{kDa}$ protein, which encapsidates the viral RNAs within the viral envelope. Virus infection in the plants may result in physiological changes which are manifested by the visible symptoms. At the molecular and cellular levels, viral proteins are recognized by the host defense machinery which results in the induction of plant defense responses like RNA silencing, hypersensitive response (HR), and stress responsive proteins (9-12). TMV resistance in the host plants is compromised at higher temperatures. During TMV infection tobacco plants (carrying the $\mathrm{N}$ gene) do not generate a hypersensitive response, and TMV spreads systemically above the $28{ }^{\circ} \mathrm{C}$ temperatures (13). Similarly, Capsicum chinense plants carrying the resistant $T s w$ gene develop systemic infections of TSWV at $32{ }^{\circ} \mathrm{C}(14)$.

Several reports have shown that during tospoviruses infection temperature is an important factor that affect the symptom expression as well as viral movement in pathogens such as Cucumber green mottle mosaic virus (CGMMV) on cucumber and melon, Cucumber mosaic virus (CMV) on melon, Melon necrotic spot virus (MNSV) on melon and TSWV on bonnet pepper (Capsicum chinense) and peanut (Arachis hypogaea) (15-20).

In the present study, we sought to predict that low temperature might limit the establishment of viral disease by lowering the accumulation of viral RNA, $\mathrm{H}_{2} \mathrm{O}_{2}$, and cell death in the host cell. Therefore, in the investigation on the effect of temperature on the viral symptom expression of the GBNV, we examined viral RNA accumulation in the GBNV inoculated leaves of the cowpea (Vigna unguiculata L.). We employed the quantitative RT-PCR reaction to estimate the GBNV replication.

\section{Objectives}

In the present study, we tried to understand the GBNV infection mechanism in cowpea plants under the four different temperatures. This study will help to design the suitable management strategy against the GBNV resistance for various crops.

\section{Materials and Methods}

\subsection{Plant Material and Virus}

GBNV inoculum was maintained on cowpea cv. Pusa komal ( $V$. unguiculata L.) grown in the growth chamber with a $14 \mathrm{~h}$ light $/ 10 \mathrm{~h}$ dark cycle at $25{ }^{\circ} \mathrm{C}$. Viral symptomatic leaves were harvested and macerated in the sterilized and chilled pestle and mortar adding 0.01 $\mathrm{M}$ phosphate buffer ( $\mathrm{pH} 7.2,1: 1, \mathrm{w} / \mathrm{v}$ ) containing $0.1 \%$ $\beta$-mercaptoethanol. The sap was extracted and used as viral inoculum for infection.

The healthy cowpea plants at the two-tree leaves stage were used for virus inoculation. The leaves were dusted with celite (as abrasive) and the extracted sap was applied directly by rubbing gently on the leaves with the chilled pestle to exert uniform pressure (21). The sap inoculated leaves were gently washed with the distilled water and were grown in a growth chamber at four different temperatures $\left(30,25,20\right.$ and $\left.15^{\circ} \mathrm{C}\right)$ with $14 \mathrm{~h} \mathrm{light} / 10 \mathrm{~h}$ dark cycle for the symptom development.

\subsection{GBNV Symptom Severity Rating}

The severity of symptoms' expression was categorized 
on the basis of phenotypic symptoms developed during viral infection. Symptom severity score was rated on a 1-point scale: $0=$ no symptoms, $0.25=$ appearance of mild chlorosis, $0.5=$ severe chlorosis, $0.75=$ yellow mosaic, and $1.0=$ necrotic spots. The infected plants were incubated at four different temperatures $(30,25$, 20 and $15^{\circ} \mathrm{C}$ ) and observed for the development of GBNV symptoms. The expressions of symptoms were scored on the basis of above mentioned scale.

\subsection{Enzyme Linked Immunosorbent Assay (ELISA) Assay for GBNV Detection}

GBNV infection in the virus inoculated plants was conformed and quantified serologically using the plate trapped-antigen enzyme linked immunosorbent assay (ELISA) method (22) in Maxisorb microtiter plates (Nunc, Roskilde, Denmark), using $50 \mathrm{mg}$ fresh leaf sample of the buffer (Mock) and GBNV inoculated cowpea plants at different stages of the symptom development; inoculated and systemic sites of the four applied temperatures $\left(30,25,20\right.$ and $\left.15{ }^{\circ} \mathrm{C}\right)$. Coating samples were prepared with the leaf tissue extract in the coating buffer (0.05 M sodium carbonate, $\mathrm{pH}$ 9.6, 1:10 $\mathrm{w} / \mathrm{v})$. Coating samples were poured into ELISA plate wells and incubated overnight at $4{ }^{\circ} \mathrm{C}$. All the further incubations for a complete ELISA procedure were performed at $37{ }^{\circ} \mathrm{C}$. For each step of the procedure, phosphate buffer saline (PBS) containing 0.05\% Tween-20 (PBS-T) was used for washing the plate and plates were washed thrice at each step of incubation. GBNV antiserum (produced in-house) was used for detection of the bound virus particles, with a dilution of 1:1000 and goat anti-rabbit alkaline phosphatase conjugated secondary antibodies (Sigma, St Louis); a dilution of 1:30,000 in PBS. p-nitrophenyl phosphate (Sigma, $1 \mathrm{mg} \cdot \mathrm{mL}^{-1}$ ) was used as the substrate for the enzyme linked to the secondary antibody. The interaction was detected and quantified with Dynatech MR 7000 plate reader at an absorbance of $405 \mathrm{~nm}$. The inoculated leaves samples were considered as positive when absorbance was exceeded twice the mean of the absorbance values for the mock-inoculated controls.

\subsection{RNA Isolation and RT-PCR for GBNV}

$50 \mathrm{mg}$ leaf sample was used for the isolation of total plant RNA from mock and virus inoculated cowpea plants maintained at four different temperatures (30, 25,20 and $15^{\circ} \mathrm{C}$ ) with different stages of symptom development as described by (23) using TRIzol reagent (Invitrogen). DNase I (Ambion) treatment was provided for the removal of DNA contamination in the isolated RNA, prior to RT-PCR analysis. For viral RNA (non-structural; NSs) transcript analysis, cDNA was synthesized from $0.5 \mu \mathrm{g}$ total RNA by $\mathrm{M}-\mathrm{MuLV}$ reverse transcriptase (NEB), using primer NSs-R 5'-TCGAGGGTTACTCTGGCTTCACAATGA AAT-3'. cDNA was then subjected to the conventional PCR. Amplification of NSs (1320 bp) was done using the oligonucleotide primers NSs-F 5'-CTGTCTAGAATGTCGACCGCAAGGAGT-3' and NSs-R 5'- TCGAGGGTTACTCTGGCTTCACAATGA AAT-3'. Amplification was confirmed on $1 \%$ agarose gel with electrophoresis.

\subsection{Quantification of Viral RNA in GBNV Inoculated Plants Using Real-time qPCR}

Total plant RNA was extracted from $50 \mathrm{mg}$ leaf material from mock and virus inoculated cowpea plants and maintained at four different temperatures $(30,25,20$ and $15^{\circ} \mathrm{C}$ ) with different stages of symptom development as described previously. The isolated RNA was treated with DNase I (Ambion, U.S.A.) prior to quantitative RTPCR analysis to eliminate genomic DNA contamination. For the viral RNA accumulation analysis, cDNA was synthesized from $0.5 \mu \mathrm{g}$ total RNA by M-MuLV reverse transcriptase (NEB) using random hexamer primers. The synthesized cDNA was then subjected to the conventional PCR and qPCR. Quantitative RT-PCR was performed using $2 X$ SYBR Green PCR Master Mix (Roche) with $20 \mathrm{ng}$ of synthesized cDNA and $5 \mu \mathrm{M}$ of each primer in $25 \mu \mathrm{L}$ reaction volume. Amplification was done using the oligonucleotide primers NSs-F 5'-ATCTGCATTCAGCATCAACG-3' and NSs-R 5'-CCTCACAACCAGGCTCATTT-3' for the GBNV NSs gene. The amplification conditions were $95^{\circ} \mathrm{C}$ for $2 \mathrm{~min}$, then 40 cycles of $95^{\circ} \mathrm{C}$ for $10 \mathrm{sec}, 55^{\circ} \mathrm{C}$ for 30 $\sec$ and $72{ }^{\circ} \mathrm{C}$ for $30 \mathrm{sec}(23)$.

\section{6. $\mathrm{H}_{2} \mathrm{O}_{2}$ Determination with Spectrophotometer}

The endogenous $\mathrm{H}_{2} \mathrm{O}_{2}$ production was estimated in the GBNV inoculated cowpea plants incubated at four different temperatures $\left(30,25,20\right.$ and $\left.15^{\circ} \mathrm{C}\right)$, as described by Frew et al. (24).

For the measurement $\mathrm{H}_{2} \mathrm{O}_{2}$ in the virus infected cowpea leaves, the $0.1 \mathrm{M}$ phosphate buffer $(\mathrm{pH} 7.2)$ was used for homogenizing the leaf sample. The extracted homogenate was centrifuged in cooled (4 ${ }^{\circ} \mathrm{C}$ ) condition at $10,000 \times \mathrm{g}$ for $10 \mathrm{~min}$. The resulted supernatant was used for estimating $\mathrm{H}_{2} \mathrm{O}_{2} .3 .0 \mathrm{~mL}$ of the prepared reagent solution $(100 \mathrm{~mL}$ contains $0.234 \mathrm{~g}$ of phenol, $0.1 \mathrm{~g}$ of 4-aminoantipyrine, $1.0 \mathrm{~mL}$ of $0.1 \mathrm{M}$ phosphate buffer, $\mathrm{pH}$ 7.2) was used for the estimation of the endogenous $\mathrm{H}_{2} \mathrm{O}_{2}$. The quantified $\mathrm{H}_{2} \mathrm{O}_{2}$ was expressed in $\mu \mathrm{moL} . \mathrm{g}^{-1}$ fresh weight. The 
spectrophotometer analysis was carried out by using the HITACHI, U-2900, spectrophotometer.

\subsection{Cell Death Detection}

The virus infection induced cell death was analyzed as described by Turner and Novacky (25) with minor modifications. The leaves of GBNV infected cowpea plants were incubated in $0.25 \%$ Evans blue solution for $20 \mathrm{~min}$ at room temperature and washed with distilled water. The trapped Evans blue was released from the virus infected cowpea leaves by homogenizing with $1.0 \mathrm{~mL}$ of $80 \%$ ethanol. The homogenate was incubated at $50{ }^{\circ} \mathrm{C}$ in a water bath for $20 \mathrm{~min}$ and centrifuged at $10,000 \times \mathrm{g}$ for 15 $\min$. The absorbance of the supernatant was measured at $600 \mathrm{~nm}$ and calculated on the basis of fresh weight.

\section{Results}

\subsection{Symptoms Expression in GBNV Infected Cowpea Plants at Different Temperatures}

GBNV inoculated cowpea plants maintained at four different temperatures $\left(30,25,20\right.$ and $\left.15{ }^{\circ} \mathrm{C}\right)$ were observed for the symptom development from the first day of viral inoculation to the complete collapse of the plant leaves. The GBNV inoculated leaves showed firstly some chlorotic symptoms within the four days of post inoculation (dpi). These chlorotic spots were converted to the necrotic spots after $8 \mathrm{dpi}$. Within these 8 days, some yellow mosaic symptoms were started to appear on the newly grown (systemic) leaves (during 30 and $25^{\circ} \mathrm{C}$ incubation) (Fig. 1a i , ii). Whereas, at 20 and $15^{\circ} \mathrm{C}$ plants showed the reduction in the viral symptom development both on inoculated and systemic sites (Fig. 1a iii , iv). At the inoculated site, these plants showed lesser chlorotic spots than those plants that were incubated at 30 and $25^{\circ} \mathrm{C}$, and surprisingly these inoculated leaves were not shown any necrotic spots up to $8 \mathrm{dpi}$. However, at systemic site, the $20^{\circ} \mathrm{C}$ incubated plants showed mild yellow mosaic symptoms at 8 dpi, but plants incubated at $15{ }^{\circ} \mathrm{C}$ did not show any viral symptoms on the systemic sites (Fig. 1a iv).

\subsection{Disease Severity Index}

The severity of GBNV symptoms expressions were scored to the plants on the basis of phenotypic symptoms developed during viral infection. The expressions of symptoms were different from the higher to lower temperature. Plants that were maintained at higher temperature $\left(30\right.$ and $\left.25{ }^{\circ} \mathrm{C}\right)$, induced higher severe symptoms-rated 0.5 to 1.0 scales. While, plants incubated at lower temperatures $\left(20\right.$ and $\left.15^{\circ} \mathrm{C}\right)$ showed reduced symptoms rating 0.25 to 0.5 scales (Fig. 1b).

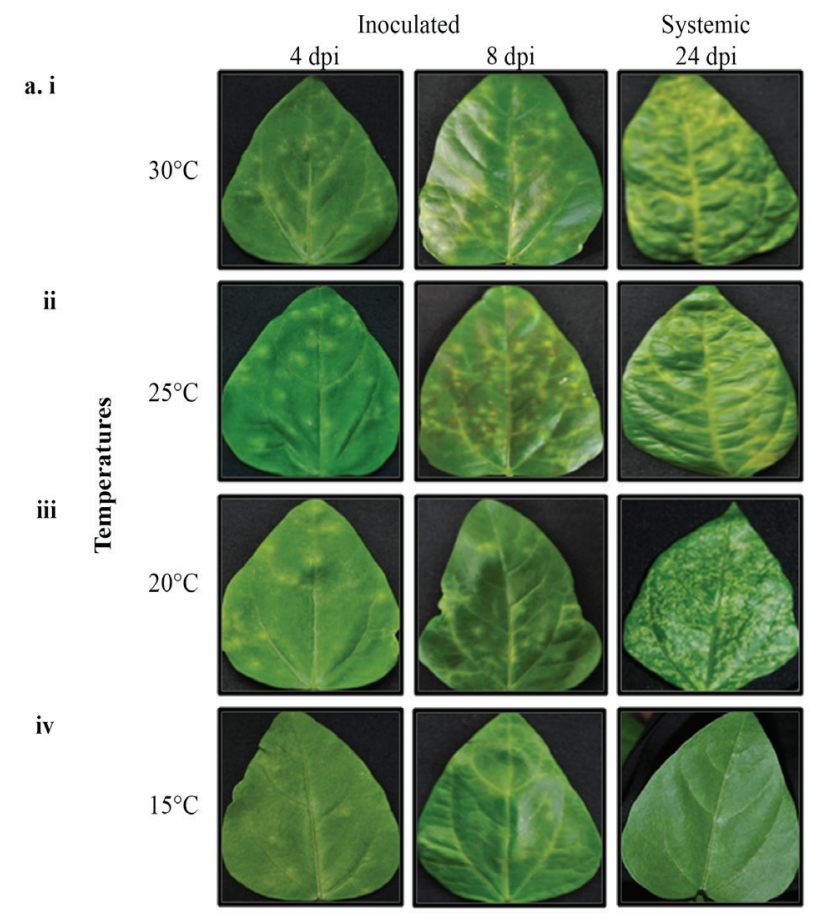

b.

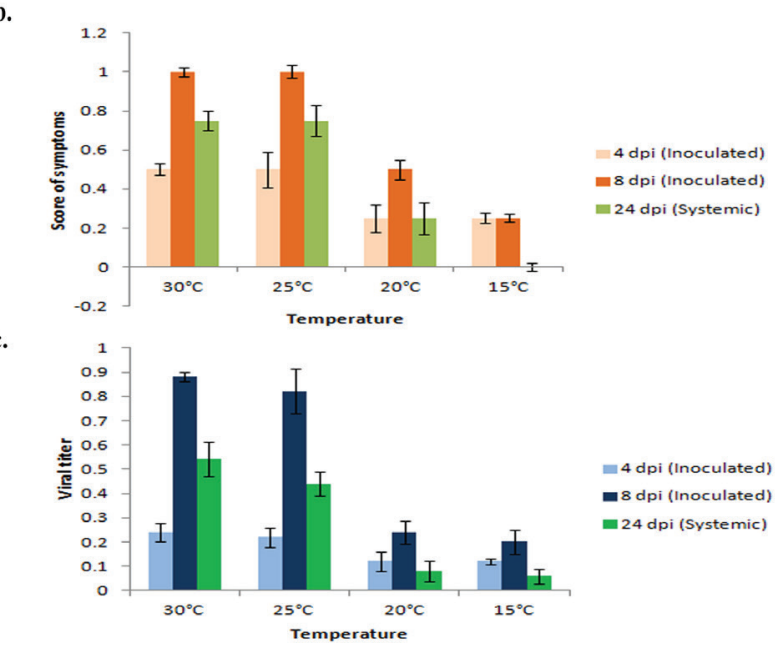

Figure 1. Different stages of symptoms development in GBNV inoculated cowpea plants, maintained at different temperatures. (a) Symptoms produced by the GBNV after mechanical inoculation on the cowpea plants in comparison to the different temperatures at the inoculated and systemic sites (i-iv). (b) Represents symptoms' severity kinetics in the GBNV inoculated cowpea plants maintained at different temperatures. Symptom severity was scored by early appearance of the mild chlorotic spots followed by severe chlorotic symptoms on leaves, which further resulted in a severe necrosis. (c) The virus accumulation kinetics in the leaves of cowpea plants. Virus titer was estimated at different stages of the viral infection maintained at different temperatures of the post viral inoculation by ELISA (O.D. $A_{405}$ ) using GBNV polyclonal antibodies (dilution 1:1000). 
4.3. Detection of GBNV in the Viral Inoculated Cowpea plants

Viral titer was estimated in the GBNV inoculated leaves of the cowpea plants maintained at different temperature $\left(30,25,20\right.$ and $\left.15^{\circ} \mathrm{C}\right)$ and days (4 and 8 days) post inoculation (dpi) with ELISA assay at OD $405\left(\mathrm{~A}_{405}\right)$. Based on ELISA values $\left(\mathrm{A}_{405}\right)$, after GBNV inoculation from 4 dpi to $8 \mathrm{dpi}$, a continuously increased and high levels of the virus accumulation was observed at the site of inoculation in the cowpea leaves at $8 \mathrm{dpi}$ (at 30 and $25{ }^{\circ} \mathrm{C} ; 0.880 \pm 0.238$, and $0.826 \pm 0.324$, respectively). In contrast, at the systemic site, during these temperatures $\left(30\right.$ and $25{ }^{\circ} \mathrm{C}$ ), ELISA values for GBNV inoculated plants at 8 dpi were $0.542 \pm 0.124$ and $0.440 \pm 0.140$, respectively. Whereas viral titer was not significantly increased in the cowpea plants at 20 and $15^{\circ} \mathrm{C}$, as compared to the plants at 30 and $25^{\circ} \mathrm{C}$. The viral titer at $20^{\circ} \mathrm{C}$ was estimated $0.240 \pm 0.024$ at $8 \mathrm{dpi}$ (i,e., inoculated site) and $0.084 \pm 0.022$ at the systemic site. Interestingly, viral titer was highly decreased in the plants maintained at $15{ }^{\circ} \mathrm{C}$ at the inoculated site $(8 \mathrm{dpi}$; $0.232 \pm 0.064)$, and at the systemic site ( $8 \mathrm{dpi} ; 0.062 \pm$ $0.024)$. The viral titer level did not differ significantly with mock plants, suggesting that virus did not reach up to the systemic site in the plant maintained at $15{ }^{\circ} \mathrm{C}$ (Fig. 1c, Table 1).

\subsection{Accumulation of Viral RNA in the GBNV in Inoculated plants}

Before the estimation of the viral RNA, viral infection was conformed with the conventional PCR by amplification of GBNV-NSs (1320 bp) gene in the GBNV inoculated cowpea plants maintained at four different temperatures $\left(30,25,20\right.$ and $\left.15^{\circ} \mathrm{C}\right)$ (Fig. 2a).

Table 1. Accumulation and detection of Groundnut bud necrosis virus (GBNV) in inoculated leaves of cowpea at different temperatures and different days post inoculation (dpi).

\begin{tabular}{|c|c|c|c|c|c|}
\hline S. No. & Temperature & Dpi and Site & $\operatorname{ELISA}\left(\mathbf{A}_{405}\right)^{a}$ & $\begin{array}{l}\text { No of positives/ } \\
\text { total plants }\end{array}$ & Symptoms Score \\
\hline \multirow{6}{*}{1} & \multirow{6}{*}{$30{ }^{\circ} \mathrm{C}$} & 4 dpi (Inoculated) & $0.242 \pm 0.012$ & $6 / 6$ & $0.50 \pm 0.024$ \\
\hline & & 8 dpi (Inoculated) & $0.880 \pm 0.238$ & $6 / 6$ & $1.00 \pm 0.146$ \\
\hline & & & & & \\
\hline & & 8 dpi (Systemic) & $0.542 \pm 0.124$ & $6 / 6$ & $7.50 \pm 0.248$ \\
\hline & & Mock & $0.062 \pm 0.014$ & $0 / 3$ & 0 \\
\hline & & 4 dpi (Inoculated) & $0.224 \pm 0.016$ & $6 / 6$ & $0.50 \pm 0.264$ \\
\hline \multirow{5}{*}{2} & \multirow{5}{*}{$25^{\circ} \mathrm{C}$} & 8 dpi (Inoculated) & $0.826 \pm 0.324$ & $6 / 6$ & $1.00 \pm 0.282$ \\
\hline & & & & & \\
\hline & & 8 dpi (Systemic) & $0.440 \pm 0.140$ & $6 / 6$ & $7.50 \pm 0.286$ \\
\hline & & Mock & $0.082 \pm 0.018$ & $0 / 3$ & 0 \\
\hline & & 4 dpi (Inoculated) & $0.122 \pm 0.012$ & $6 / 6$ & $0.25 \pm 0.284$ \\
\hline \multirow{5}{*}{3} & \multirow{4}{*}{$20{ }^{\circ} \mathrm{C}$} & 8 dpi (Inoculated) & $0.240 \pm 0.024$ & $6 / 6$ & $0.50 \pm 0.280$ \\
\hline & & & & & \\
\hline & & 8 dpi (Systemic) & $0.084 \pm 0.022$ & $3 / 6$ & $0.25 \pm 0.260$ \\
\hline & & Mock & $0.041 \pm 0.012$ & $0 / 3$ & 0 \\
\hline & \multirow{5}{*}{$15^{\circ} \mathrm{C}$} & 4 dpi (Inoculated) & $0.122 \pm 0.014$ & $6 / 6$ & $0.25 \pm 0.248$ \\
\hline \multirow{4}{*}{4} & & 8 dpi (Inoculated) & $0.232 \pm 0.062$ & $6 / 6$ & $0.25 \pm 0.246$ \\
\hline & & & & & \\
\hline & & 8 dpi (Systemic) & $0.062 \pm 0.024$ & $0 / 6$ & 0 \\
\hline & & Mock & $0.062 \pm 0.014$ & $0 / 3$ & 0 \\
\hline
\end{tabular}

${ }^{a}$ Values are mean absorbance and standard deviation $( \pm \mathrm{SD})$ at $405 \mathrm{~nm}$ in the enzyme-linked immunosorbent assay (ELISA) analysis $(\mathrm{n}=6)$. Means followed by different letters are significantly different by Scheffe's test $(p<0.05)$

${ }^{b}$ Number of GBNV positive plants/total inoculated plants. 
a.

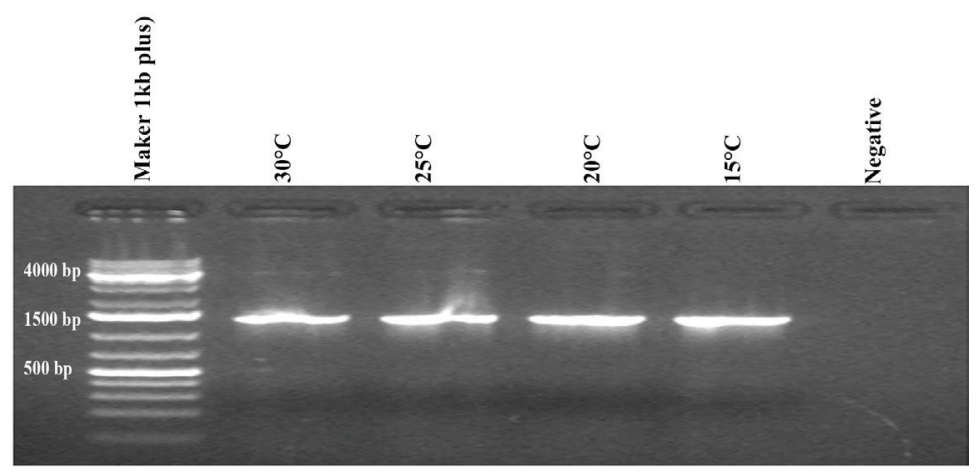

b. $\mathrm{i}$

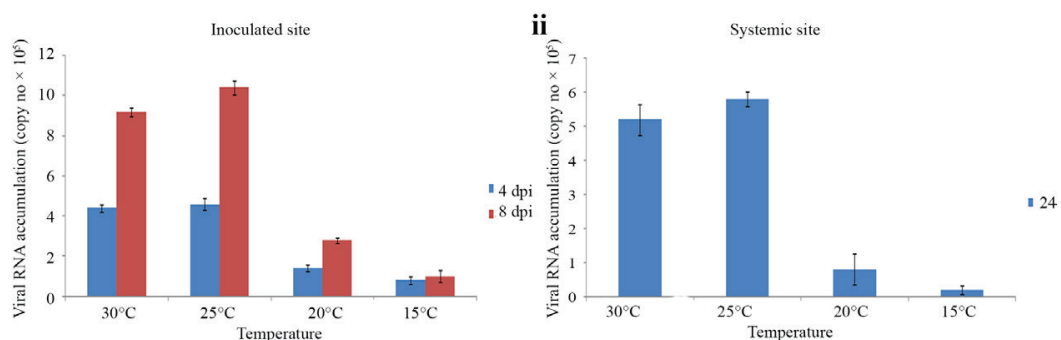

c.
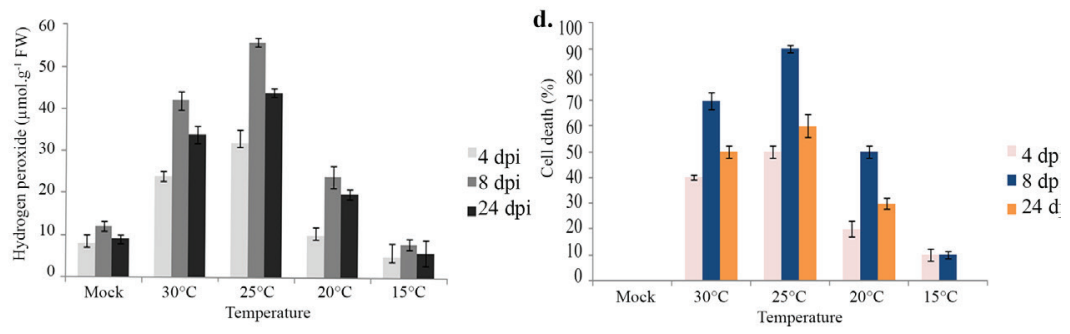

Figure 2. Accumulation of the viral RNA and $\mathrm{H}_{2} \mathrm{O}_{2}$ and induction of the cell death kinetics in the GBNV inoculated cowpea plants incubated at the different temperatures. (a) RT-PCR gel electrophoresis results confirming viral infection in the cowpea plants maintained at the different temperatures $\left(30,25,20\right.$ and $\left.15^{\circ} \mathrm{C}\right)$. (b) $\mathrm{RT}-\mathrm{qPCR}$ quantification of the GBNV RNA with amplification of the $5^{\prime}$ end of the small segment (NSs) of the viral genome (nucleotides 146-297). The copy number of the transcript per $\mathrm{mL}$ of the sample was plotted at different stages of (i) inoculated and (ii) systemic sites of infection. (c) $\mathrm{H}_{2} \mathrm{O}_{2}$ accumulation and (d) induction of the cell death in the GBNV infected cowpea leaf samples at the inoculated and systemic sites following to four different applied temperatures. Error bar represent \pm standard deviation (SD) of the mean data in three independent experiments.

Viral RNA accumulation analysis using RT-qPCR showed that accumulation was continuously increased (4.4-10.4 $\times 10^{5}$ copy no. ; Supplementary material) in the plants maintained at 30 and $25^{\circ} \mathrm{C}$ from 4 dpi to 8 dpi at the inoculated site (Fig. 2bi). During this time period (4-8 dpi), the virus also moves from the inoculated to the systemic site at $30{ }^{\circ} \mathrm{C}$ and accumulates about 5.2 $\times 10^{5}$ viral copy, while at $25^{\circ} \mathrm{C}$, plant accumulates viral copy of about $5.8 \times 10^{5}$ at the systemic site (Fig. 2b ii). Plants incubated at $20{ }^{\circ} \mathrm{C}$ accumulate a lower viral copy $\left(2.8 \times 10^{5}\right.$; at $\left.8 \mathrm{dpi}\right)$ than the plants incubated at $30{ }^{\circ} \mathrm{C}$ and $25^{\circ} \mathrm{C}$ (Fig. 2bi), and during this time ( 8 dpi) and temperature at $20^{\circ} \mathrm{C}$, much lesser viral copy $(0.8$ $\times 10^{5}$ ) was observed at systemic site (Fig. 2b ii). This showed that reduction in the temperature decreased viral movement to the systemic site. Interestingly, plants incubated at $15^{\circ} \mathrm{C}$ accumulate much less copy of the viral RNA both at the inoculated $\left(1.0 \times 10^{5}\right)$ (Fig. 2bi) and systemic sites $\left(0.2 \times 10^{5}\right)$ (Fig. $2 \mathrm{~b}$ ii) at $8 \mathrm{dpi}$. This data suggest that low temperature reduced the viral movement as well its replication in the host plant.

\subsection{Lower Temperature Incubation Reduced the} Accumulation of $\mathrm{H}_{2} \mathrm{O}_{2}$ and Cell Death than the Higher Temperature

$\mathrm{H}_{2} \mathrm{O}_{2}$ accumulation was analyzed in the plants incubated at four different temperatures $\left(30,25,20\right.$ and $\left.15^{\circ} \mathrm{C}\right)$. A higher $\mathrm{H}_{2} \mathrm{O}_{2}$ accumulation was observed in the GBNV inoculated cowpea plants incubated at higher (30 and 25 ${ }^{\circ} \mathrm{C}$ ) temperature both at the inoculated and the systemic sites than the plants incubated at a lower temperature $\left(20^{\circ} \mathrm{C}\right)$. Interestingly, $\mathrm{H}_{2} \mathrm{O}_{2}$ accumulation was drastically 
reduced in the plants incubated at $15^{\circ} \mathrm{C}$ temperature at both inoculated and systemic sites (Fig. 2c).

To identify the role of temperature in the virus induced leaf cell death, the virus infected cowpea plants incubated at four different temperatures were analyzed for the cell death by Evans blue staining. Plants incubated at higher temperatures $\left(30\right.$ and $\left.25^{\circ} \mathrm{C}\right)$ were observed to be more induced (40-90\%) for the cell death both at the inoculated and systemic sites. While plants incubated at $20^{\circ} \mathrm{C}$ showed a lower (20-50\%) cell death during virus infection than plants incubated at higher temperatures. Surprisingly those plants incubated at 15 ${ }^{\circ} \mathrm{C}$ showed only $10 \%$ cell death at the inoculated site and no cell death was observed at the systemic site at this temperature (Fig. 2d).

\section{Discussion}

The present study showed that the severity and viral RNA accumulation of the GBNV infection is temperature dependent, and the high temperature (30 and $25^{\circ} \mathrm{C}$ ) facilitated symptom expression and viral spread in the cowpea plants. The pattern of symptom expression also depends on the temperature and the host-virus combination (15). Temperature affects viral accumulation and spread inside the plant, host susceptibility, as well as viral symptom expression (1). Tomato infected with TSWV accumulated higher viral RNA at $20^{\circ} \mathrm{C}$ and severe symptoms at $36{ }^{\circ} \mathrm{C}(1)$. TSWV inoculated $C$. chinense induced more systemic infection at $30 / 18{ }^{\circ} \mathrm{C}$ (day/night) than at $25 / 18{ }^{\circ} \mathrm{C}(15)$. Whereas, TSWV inoculated peanut plants resulted in a higher resistance and reduced systemic infection at the higher temperature $\left(30-37^{\circ} \mathrm{C}\right)$ than the lower temperature $\left(25-30{ }^{\circ} \mathrm{C}\right)(16)$. Llamas-Llamas et al. (1) have reported that at higher temperature $\left[29 / 24^{\circ} \mathrm{C}\right.$ (day/ night)], TSWV induced viral symptoms both at the local and systemic site in Nicotiana tabacum and Datura stramonium. At low temperatures, TSWV infected tobacco results to only local lesions (chlorotic rings), while at high temperatures both local and systemic symptoms develop (26). In the case of GBNV, higher temperatures $\left(30\right.$ and $\left.25^{\circ} \mathrm{C}\right)$ facilitate the induction of the viral symptoms and spread from inoculated to the systemic sites in cowpea.

As expected, at the higher temperature (30 and 25 ${ }^{\circ} \mathrm{C}$ ), plants accumulated the higher viral titer and RNA. The onset of symptom development and severity were associated with the virus titer in the host cells and clearly suggested major changes in the host plants metabolism. RNA silencing mediated plant defenses was temperature-dependent and the levels of siRNAs increased gradually with rising temperatures (27).
TCV infection in Arabidopsis thaliana is facilitated more vigorously at a higher temperature than the lower temperatures (2). Our study also reproves that higher temperature favors the viral replication and symptoms severity. In the present study, GBNV infected plants showed fewer symptoms and a reduced viral accumulation at the lower temperatures $\left(20\right.$ and $\left.15^{\circ} \mathrm{C}\right)$. We hypothesize that reduction of the viral symptom is evident when replication is reduced, viral movement slowed, viral suppressor levels decrease, or host plant resistance increases. A recent report (28) showed that the Potato virus $Y$ and Potato virus $X$ titers in addition to viral RNA were increased at higher temperatures.

We previously have reported that GBNV infection induced its typical symptoms (chlorosis and necrosis) within 4-8 dpi in a mechanically inoculated cowpea plants and GBNV infection was spread systemically at 8 dpi which instigate the two types of cell death at the inoculated (necrosis) and systemic site (premature senescence) at $25{ }^{\circ} \mathrm{C}$. The necrotic site of the virus inoculation accumulates more $\mathrm{H}_{2} \mathrm{O}_{2}$ which play a central role in the virus induced programmed cell death (PCD) than the non-inoculated (systemic) sites (29). In this study, we confirmed that viral symptoms (chlorosis, necrosis, and yellow mosaic) and viral spread of GBNV is temperature dependent, and a lower temperature (20 and $15^{\circ} \mathrm{C}$ ) limits viral infection in cowpea.

Several studies have suggested that the presence of the virus generally diminishes the photosynthetic capacity by decreasing the accumulation of the photosynthetic proteins in the infected plants $(11,12)$. This study has shown that the accumulation of virus is affected by the temperature regime to which the plants are exposed. Overall, the results of the present study clearly show that the viral response (infection and spread) is more active at the higher temperature than the lower temperature. Genetic analyses and further detailed studies are needed to clarify these mechanisms in cowpea plants.

\section{Acknowledgments}

We thank C. B. Yadav for his helpful comments and discussions. We are thankful to the University Grants Commission (UGC), New Delhi for providing fellowship to AS. We are also thankful to IARI, New Delhi for providing the facility for this work.

\section{Supplementary Material}

This paper includes a supplementary file containing the accumulation of Viral RNA using RT-qPCR in the plants which is appeared on the web site of the IJB journal (http://www.ijbiotech.com). 


\section{References}

1. Llamas-Llamas ME, Zavaleta-Mejia E, Gonzalez-Hernandez VA, Cervantes-Diaz L, Santizo-Rincon JA, Ochoa-Martinez DL. Effect of temperature on symptom expression and accumulation of tomato spotted wilt virus in different host species. Plant Pathol. 1998;47:341-347. doi: 10.1046/j.13653059.1998.00249.x

2. Zhang X, Zhang X, Singh J, Li D, Qu F. Temperature-dependent survival of Turnip crinkle virus-infected arabidopsis plants relies on an RNA silencing-based defense that requires dc12, AGO2, and HEN1. J Virol .2012;86:6847-6854. doi: 10.1128/ JVI.00497-12

3. Prasch CM, Sonnewald U. Simultaneous application of heat, drought, and virus to Arabidopsis plants reveals significant shifts in signaling networks. Plant Physiol. 2013;162:18491866. doi: 10.1104/pp.113.221044

4. Zhong SH, Liu JZ, Jin H, Lin L, Li Q, Chen Y, et al. Warm temperatures induce transgenerational epigenetic release of RNA silencing by inhibiting siRNA biogenesis in Arabidopsis. Proc Natl Acad Sci. U.S.A. 2013;110:9171-9176. doi: 10.1073/ pnas. 1219655110

5. Ghoshal B, Sanfaçon H. Temperature-dependent symptom recovery in Nicotiana benthamiana plants infected with tomato ringspot virus is associated with reduced translation of viral RNA2 and requires ARGONAUTE 1. J Virol. 2014;456:188197. doi: 10.1016/j.virol.2014.03.026

6. Patil BL, Fauquet CM. Light intensity and temperature affect systemic spread of silencing signal in transient agroinfiltration studies. Mol Plant Pathol. 2015;16:484-494. doi: 10.1111/ mpp. 12205

7. de Haan P. Exploring and exploiting the RNA genome of tomato spotted wilt virus. Ph.D. thesis, Wageningen Agricultural University. 1991.

8. Maiss E, Ivanova L, Breyel E, Adam G. Cloning and sequencing of the S RNA from a Bulgarian isolate of tomato spotted wilt virus. J Gen Virol. 1991;72:461-464. doi: 10.1099/0022-131772-2-461

9. Chellappan P, Vanitharani R, Ogbe F, Fauquet CM. Effect of temperature on geminivirus-induced RNA silencing in plants. Plant Physiol. 2005;138:1828-1841. doi: 10.1104/ pp.105.066563

10. Zvereva AS, Pooggin MM. Silencing and innate immunity in plant defense against viral and non-viral pathogens. Viruses. 2012;4:2578-2597. doi:10.3390/v4112578

11. Obrepalska-Steplowska A, Wieczorek P, Budziszewska M, Jeszke A, Renaut J. How can plant virus satellite RNAs alter the effects of plant virus infection? A study of the changes in the Nicotiana benthamiana proteome after infection by Peanut stunt virus in the presence or absence of its satellite RNA. Proteomics. 2013;13:2162-2175. doi: 10.1002/pmic.201200056

12. Fang X, Chen J, Dai L, Ma H, Zhang H, Yang J, et al. Proteomic dissection of plant responses to various pathogens. Proteomics. 2015;15:1525-1543. doi: 10.1002/pmic.201400384

13. Erickson FL, Dinesh-Kumar SP, Holzberg S, Ustach CV, Dutton M, Handley V, Corr C, Baker BJ. Interactions between tobacco mosaic virus and the tobacco N gene. Phil. Trans. R. Soc. Lond B Biol Sci. 1999;354:653-658. doi: 10.1098/rstb.1999.0417

14. Roggero P, Pennazio S, Masenga V, Tavella L. Resistance to tospoviruses in pepper. In: Thrips and tospoviruses: Proceedings of the 7th International Symposium on Thysanoptera, eds. by R. Marullo and L. Mound.1996 pp. 105-110. Australian National Insect Collection, Canberra, Australia.

15. Soler S, Diez MJ, Nuez F. Effect of temperature regime and growth stage interaction on pattern of virus presence in TSWV resistant accessions of Capsicum chinense. Plant Disease. 1998;82:1199-1204. doi: 10.1094/PDIS.1998.82.11.1199

16. Mandal B, Pappu HR, Culbreath AK, Holbrook CC, Gorbet DW, Todd JW. Differential response of selected peanut (Arachis hypogaea) genotypes to mechanical inoculation by Tomato spotted wilt virus. Plant Disease. 2002;86:939-944. doi: 10.1094/PDIS.2002.86.9.939

17. Kido K, Tanaka C, Mochizuki T, Kubota K, Ohki T, Ohnishi J, Knight LM, Tsuda S. High temperatures activate local viral multiplication and cell-to-cell movement of Melon necrotic spot virus but restrict expression of systemic symptoms. Phytopathol. 2008;98:181-186. doi: 10.1094/PHYTO-98-2-0181

18. Mallor C, Alvarez JM, Luis-Arteaga M. A resistance to systemic symptom expression of Melon necrotic spot virus in melon. $J$ Amer Soc Hort Sci. 2003;128:541-547. doi: 10.1023/B:EUPH $0000004969.95036 .1 \mathrm{~d}$

19. Moreno IM, Thompson JR, Garcia-Arenal F. Analysis of the systemic colonization of cucumber plants by Cucumber green mottle mosaic virus. J GenVirol. 2004;85:749-759. doi: 10.1099/vir.0.19540-0

20. Sugiyama M, Ohara T, Sakata Y. A new source of resistance to Cucumber green mottle mosaic virus in melon. J Japan Soc Hort Sci. 2006;75:469-475. doi: 10.2503/jjshs.75.469

21. Vemana K, Jain RK. Biological similarities and differences between tobacco streak virus and groundnut bud necrosis virus infecting groundnut (Arachis hypogea). Indian Phytopathol. 2012;65:177-183. doi: 10.1007/s13337-013-0160-1

22. Sahana N, Kaur H, Basavaraj Tena F, Jain RK, Palukaitis P, Canto T, Praveen S. Inhibition of the Host Proteasome Facilitates Papaya Ringspot Virus Accumulation and Proteosomal Catalytic Activity Is Modulated by Viral Factor HcPro. PLoS One. 2012;7(12):e52546. doi: 10.1371/journal.pone.0052546

23. Koundal V, Vinutha T, Mohd Q, Haq R, and Praveen S. Modulation of Plant Development and MYB Down Regulation : Both during In Planta Expression of miR159a and in Natural ToLCV Infection. J Plant Biochem Biotechnol. 2010;19:171175. doi: 10.1007/BF03263337

24. Frew JE, Jones P, Scholes G. Spectrophotometric determination of hydrogen peroxide and organic hydroperoxides at low concentrations in aqueous solution. Analytica Chimica Acta. 1983;155:139-150. doi: 10.1016/S0003-2670(00)85587-7

25. Turner JG, Novacky A. The quantitative relationship between plant and bacterial cells involved in the hypersensitive reaction. Phytopathology. 1974;64(6):885-890. doi: 10.1094/ Phyto-64-885.

26. Lawson RH, Dienelt MN, Hsu HT. Influence of temperature on the ultrastructure and serological reactivity of two Tospovirus isolates. Acta Horticulturae. 1994;377:149-57. doi: 10.17660/ ActaHortic.1994.377.15

27. Szittya G, Silhavy D, Molnár A, Havelda Z, Lovas A, Lakatos L, Bánfalvi Z, Burgyán J. Low temperature inhibits RNA silencing-mediated defence by the control of siRNA generation. EMBO J. 2003;22:633-640. doi 10.1093/emboj/cdg74

28. Del Toro FJ, Aguilar E, Hernández-Walias FJ, Tenllado F, Chung BN, Canto T. High temperature, high ambient $\mathrm{CO}_{2}$ affect the interactions between three positive sense RNA viruses and a compatible host differentially, but not their silencing suppression efficiencies. PLoS One. 2015;10:e136062. doi: 10.1371/journal.pone.0136062

29. Permar V, Singh A, Pandey V, Alatar AA, Faisal M, Jain RK, Praveen S. Tospo viral infection instigates necrosis and premature senescence by micro RNA controlled programmed cell death in Vigna unguiculata. Physiol Mol Plant Pathol. 2014;88:77-84. doi: 10.1016/j.pmpp.2014.09.004 